\title{
Bánlaky Pál
}

\section{ÖNÉLETÍRÁS - RÉSZLETEK}

DOI 10.35402/kek.2020.3.11

\begin{abstract}
Absztrakt
$\mathrm{Az}$ írásban szerző memoárjának („Megéltem nyolc évtizedet") a részletei szerepelnek. Mégpedig nem tartalmi részek, hanem olyan mögöttes dolgok, („meta-problémák”), amik magára a megírásra vonatkoznak. (A könyvben ezek közbenső meditációkként - „Intermezzo” alcímeken - szerepelnek). Felvet lélektani-ismeretelméleti kérdéseket: hogyan működik, mennyire megbízható az emlékezet? Mi az, amit töröl, és miért töröl olykor nagyon lényeges elemeket is? És egyáltalán: mennyi írható le egy életből? A teljességet lehetetlen, szükségképpen szelektálni kell. Vajon mindig a lényegest tarja-e meg az emlékező? (Válasza: biztosan nem. Mert a szelekcióban ott van az értékelés is, az emlékező azt tartja meg, amit jónak, elfogadhatónak ítél. Bűneit az ember szívesen elfelejti...)
\end{abstract}

\section{Short abstract}

In this essay, based on his own book "I have lived for eight decades," the author addresses the problems of writing a memoir. He discusses the psychological and epistemological questions regarding human memory. Also, he reflects on if writing down emotions and feelings is possible at all. Furthermore, the author raises ethical considerations that memoir authors might face concerning other people who appear in the life story narrative. He also describes how the written life story finally separates from the author.

Pár éve létrejött memoárom, önéletírásom „Mesélek magamról" munka-cimmel. (Javitott - szükitett és szerkesztett - változata meg is jelent 2018-ban a Wesley János Kiadónál, „Megéltem nyolc évtizedet” címen.) Mesém persze alapvetöen arról szól, ami történt velem, meg ahogyan átéltem a történéseket. De irás közben elökerültek "meta-problémák" is, olyan mögöttes dolgok, amik magára a megirásra vonatkoznak. Többek között az emlékezés sajátosságairól, az érzések szavakba foglalásának nehézségeiröl, a leirás dilemmáiról és azon belül például arról, mit és mennyit irhatok le másokról. A kimondhatóság problémái: sokszor másokat is érinthet mondanivalónk. Szociológiában nem ritka: ha interjuzunk, az alany esetleges megnevezése érinti a beszélöt, de az is elöfordul - föleg a helyi társadalom kutatásában -, hogy az interjúalany másróllmásokról is beszél. (Például szidja a polgármestert, vagy dicséri a papot.) Mennyit szabad mindebböl a szövegünkben benne hagyni, mikortól kell - igy szoktuk mondani - „anonimizálni” az elmondottakat? De probléma lehet a megírhatóság is: kellóen egyértelmüek-e a használni kivánt fogalmak, megtaláljuk-e a megfelelo" mondat-szerkezetet, stb. Meditációk tehát az emlékirás ismeretelméleti (gnoszeológiai) és morális (etikai) problémáiról szól.

Elég sok efféle gondom volt könyvem irása közben; „közbevetésekként” fogalmaztam meg öket. Ezekböl a meditációkból gyüjtöttem össze egy csokorra valót. Ami így persze nem logikusan végiggondolt, egyivü tanulmány, csak egymáshoz hol szorosabban, hol lazábban kapcsolódó töprengések. De tán nem érdektelen igy sem.

És még egy megjegyzés. Már eme "gyüjtemény” öszszeállitása után került kezembe Heller Ágnes könyve, „Az önéletrajzi emlékezés filozófiája” cimen. Megriadtam: ha ezt már Heller Ágnes megirta, mit akarhatok én? Elolvastam, megnyugodtam. (Kissé.) Mert a dolog nem ugyanarról szól. Heller az emlékezés sajátszerüségeiröl ir, én a megírás (vagy leirás) problémáiról. Talán amit én teszek, egyfajta konkretizációja annak, amiröl Heller filozófiai elméletet ir. Mindenesetre az érdeklödo" olvasónak is melegen figyelmébe ajánlom Heller könyvét.

\section{Az emlékírás dilemmái - avagy miért kell mégis csinálni azt, ami lehetetlen}

Kell csinálni az emlékírást, mert vénülvén eljő az ideje a számvetésnek, amivel tartozom első soron magamnak, de tán másoknak is, mindenekelőtt fiaimnak: joguk van tudni, ki volt és miként élt az apjuk. És majdhogynem lehetetlen a számvető emlékezés, mert... - erről szól ez az írás.

Egy változat az emlékirás, "müfajáról": a "mesélés" (Îgy kezdtem el azt a memoárt:) 


\section{Mire megvénülünk.}

Lopom Jókai egy regényének címét felütésnek.

Vajon a „mire megvénülünk” felütés elég „ütős” ahhoz, hogy kíváncsivá tegye az olvasót?

Aztán, megvénültem-e már? Korom szerint, 78 éves lévén (annyi voltam, amikor elkezdtem a „mesélést”), vénembernek számíthatok. De valójában mégsem igaz. Hiszen nem szabad megvénülnöm, mivel 15 éves a fiam, valahogy még föl kell nevelnem. És nem tudok, nem akarok megvénülni, mert a fóiskolán, ahol tanítok, olyan órákat tartok, amiknek egy részéről azt mondják a hallgatók, hogy jó volt. Tehát tudok még valamit adni. Akkor megvénültem már? Igen is, meg nem is. De, ha abból indulok ki, hogy korom szerint vén vagyok, hát akkor itt az ideje, hogy mérleget csináljak az életemről. De tudok-e mérleget csinálni? Tudok-e mérleget csinálni, van-e elég erőm és információm ahhoz, hogy ezt megtegyem? Információm? Igen. Mert kérdés, hogy mire emlékszem az életemből, és mire nem? Nagyon sok mindenre emlékszem, de nagyon sok mindenre nem. Erről majd később lesz még szó.

Végül is úgy döntöttem, hogy mesélek. Mesélek az életemről.

Most itt ülök, kezemben egy diktafonnal. És elkezdem.

Megéltem 78 évet (eddig). Benne egy világháborúval, benne, egy forradalommal, benne egy úgynevezett rendszerváltozással, végigcsináltam sok mindent, voltam ministráns, harangozó, voltam úttörő, csapattanácselnök, voltam DISZ-tag, iskolai DISZ-titkár, sok minden voltam. Erről mindről mesélni kell. Igen, mert az, amit megéltem, abban benne van a történelem, benne vannak a társadalmi változások, benne vagyok én. Én, aki valahogy megéltem mindezt, ahogy valamiképpen reagáltam minderre, ahogy bennem valahogy mindez lecsapódott. Lehet, hogy ez mások számára is érdekes lehet. Rajta hát!

\section{Pár mondat a mese természetrajzáról}

Megkísérlem elmesélni magamat, igen, magamat elmesélni. Nem feltétlenül magamról, mert ha magam ról mesélek, az azt jelenti, hogy valakiről valaki mesél. Ha magamról mesélnék, azt jelentené, hogy én mesélek énrólam; kettészakadt én. És tényleg ez van; ez itt van bennünk és bennem is. Kívülről is nézem magamat, meg megpróbálom belülről megérteni magamat. És nem tudom, lehetséges-e magamat úgy elmesélni, hogy csak én legyek benne.
Ne legyen ez a kettőzött én. Hogy én legyek az, aki mesél, és nem mást, magamat mesélem, csak magamat, aminek én gondolom magamat. Persze, hogy csak azt mondhatom, aminek én gondolom magamat, hiszen hogy más mit gondol rólam, az egy másik dolog. Azt ők mondják el, ha akarják, ha tudják, ha merik. Nekem azzal, hogy mások mit gondolnak rólam, most ebben a pillanatban nincs közöm. Én csak azt akarom elmondani, hogy én mit gondolok magamról. Tehát: magamat mesélem. Mondom, amire emlékezni tudok, és amire emlékezni merek. Mert korlátozott és korlátolt az emlékezet, ezt tudomásul kell venni.

A memoár az emlékezés műfaja. Akkor hát nézzünk meg egy adalékot az emlékezet lélek-müködéséröl!

Hogyan (is) müködik az emlékezet, és még az emlékek érvényességéről

Gyerekkoromban - 1940-es évek eleje, olyan 3-6 éves kor között - Székesfehérváron éltünk, apám a Magyar Nemzeti Bank fiókfönöke volt. Ehhez a státuszhoz természetesen személyzet is tartozott. Volt mellettünk (hárman voltunk testvérek) egy gyereklány, Anni. Sváb lány volt, és egyebek között azt is utasításba kapta, hogy velünk csak németül beszélhet. Így én gyakorlatilag egyszerre tanultam meg németül és magyarul. És nagyon szerettem Annit. '44-ben el kellett mennie tőlünk. Én nagyon sírtam akkor, és attól kezdve nem voltam hajlandó megszólalni németül. Anyám-apám sokszor próbálták (mindketten perfekt beszélték a nyelvet), én nem és nem és nem; mai napig sem.

Azt gondolom, hogy ez a történet Annin kívül nem csak róla szól. Arról szól, hogy az én belső működésmódom valamiképpen úgy dolgozik, hogy egy erős negatív élmény nagyon sok mindent leblokkol és visszafojt. Lehet, hogy ez freudi alapon könnyen magyarázható az elfojtások természetrajzával, de ez az én élményem. S Freud vagy nem Freud, az az én élményem, hogy vannak emlékeim, vagy élmény-morzsáim, vagy olyan emlékeim, ahol nem konkrét esetre, nem konkrét arcra, nem konkrét történésre emlékszem, hanem csak egy érzésre, egy benyomásra, és ezek az emlékek, ezek az érzések, ezek a benyomások, ha negatívak, akkor leblokkolják a történésekre való emlékezést. A történésekre? Nemcsak a történésekre. Mondtam, hogy Annit én nagyon szerettem. És nyilván több éven keresztül volt velem, mellettem, hiszen másképp nem tudtam volna németül megtanulni tőle. De az arcára, 
a hajára, semmire nem emlékszem. Nem emlékszem, hogy hogyan nézett ki. Nem emlékszem, hogy mennyi idős volt. Nem emlékszem, hogy milyen ruhákat hordott. Nem emlékszem semmi konkrétumra. Nem emlékszem arra, hogy hogyan játszott vagy mit játszott, vagy mit csinált velem. Csak arra emlékszem, hogy Anni volt, Anni nekem nagyon fontos volt, elszakitották tölem, és innentöl kezdve minden vele kapcsolatos konkrét emlékem is kitörlödött, lefojtódott. Ezzel azóta sem tudok mit kezdeni, mint ahogy azzal sem, hogy ez a furcsa, részleges amnézia máskor, más személyekkel, más esetek kapcsán is így müködik.

Egy másik adalék, ugyanerről.

Életem első nagy - három és fél évig tartó - szerelme Panni volt. Akivel kapcsolatunk megszakadása - ő szakított - nekem nagyon fájdalmas élmény volt, olyannyira, hogy utána évekig nem tudtam újabb kapcsolatba belemenni. És emlékképe, meg az érzés emléke évtizedekig bennem élt. $S$ mindig felsejlett előttem egy arc, egy alak, nagyon világos, pontos, tiszta vonalakkal. Egészen addig, míg egyszer, már nagyon-nagyon sokkal az elválásunk után, évtizedekkel később a kezembe került egy fotóalbum, ami rólunk szólt. Amibe a róla vagy kettőnkről készült képek voltak összegyüjtve. $S$ ez az album az elválásunk óta nem volt a kezemben. Abban az értelemben nem volt a kezemben, hogy nem néztem bele, nem lapoztam bele. Vittem magammal mindig a többi fotóalbum között, tudtam, hogy ott van, rendben van, megvan, de nem néztem bele; nyilván nem véletlenül hagytam nyitatlanul. Mondom, egyszer, tíz-tizenkét évvel ezelőtt, tehát már több mint harminc-negyven évvel a kapcsolat elmúlta után, megint a kezembe került az album és akkor, ki tudja, miért, belelapoztam. $S$ ott volt az első oldalon mindjárt egy portré róla, amit én készitettem, egy jó fénykép. És döbbenetes volt, hogy erről nem az az arc nézett vissza rám, mint ami az emlékeimben élt. Persze, ismerős volt az arc, és abban a pillanatban, amint a fényképre ránéztem, tudtam, hogy igen, persze ő az. De az emlékeimben nem az az arc élt. Nem tudom megmagyarázni, hogy miben különbözött, de más volt. (Az emlékarcot azóta soha nem tudom felidézni...) Az emlék átszinezte az arcot. Nem törölte, átszinezte. Anni arcát törölte. Panni arcát nem törölte, hanem átalakította. Miért? Mert nagyon fontos volt nekem, és valamiért (az elválás módja miatt? - valószínűleg azért) az eredetit törölni akarta. Éppúgy, mint Annit. Az elválásunk módja olyan volt, olyan élmény volt, ami az előzőket éppúgy, mint Anni esetén, törölni akarta. És konstruált helyette egy másikat. Szebbet nem. Csak másmilyet. Mert valamilyenre, egy konkrét arcra mindenképpen szüksége volt az emlékezésnek. Nagyon furcsa érzés volt. Nagyon sejtelmes, $s$ azóta, ha rágondolok, már megint csak az eredeti, a fényképen látott arc elevenedik meg előttem. Előhívta a fénykép az igazi arcot. S azóta az van bennem. Ugyanolyan erősen, intenzíven és követelően, ha tetszik, mint a konstruált arc. Az él bennem. Megint valóságossá lett? Talán igen.

Így (is) működik az emlékezet. Töröl, alakít? Persze.

Gondoljunk csak bele! Ha egy sok év előtti történést - emlékeimből - felidézek, soha nem azt idézem fel, ami volt, ami történt, hanem mindig csak azt, ahogyan most gondolok rá. És itt fontos azt is hangsúlyozni, hogy most hogyan gondolom. De ahogyan most visszatekintve felidézek dolgokat, nyilvánvalóan ez a visszatekintés egy meghatározott állapotból, egy meghatározott helyzetből való viszszatekintés. Valahová eljutottam. Kialakult a világgal, a környezetemmel, a társadalommal valamilyen viszonyom, s teljesen természetesnek tartom, hogy amikor nekilátok felidézni az utat, az én utamat, ami ide elvezetett, akkor maga a nézőpont, ahonnan most szemlélem, már befolyásolja azt, ahogyan megpróbálom értelmezni azokat a dolgokat, amik történtek velem, vagy amiket csináltam. Sőt biztos, hogy nem csak az értelmezést befolyásolja a mostani álláspontom, nézőpontom, helyzetem. Biztos, hogy befolyásolja azt is, hogy mire emlékszem vissza. Mi az, ami felidéződik? Igen, az emlékezet, az emlékezet itt is, mint annyi más dologban müködik valahogy, működik úgy, hogy megőriz, felidézhetővé tesz dolgokat, $s$ vannak dolgok, amiket töröl. Valószínúleg azokat a dolgokat törli, amik ma, mai gondolkodásom szempontjából kínosak lennének, negatív színben tüntetnének föl. De hát nem tudunk vele mit kezdeni, mert az emlékezet ebben az értelemben nem befolyásolható. Van, amit megőriz, van, amit töröl. Felidézni csak azt tudom, amit megőrzött. Nem tudok a törléssel mit kezdeni, mert hiszen nem tudom, hogy mit törölt. Pedig lehet, hogy fontos dolgokat is törölt. Ezzel a bizonytalansággal bizony együtt kell élni, s amikor mesélek, akkor ebben ott van ez a bizonytalanság. Egyet merhetek, vagy próbálhatok meg, legalábbis a magam számára hangsúlyosan lerögzíteni. Hogy szándékosan nem hallgatok el semmit. Ami az emlékezetben előjön, azt megpróbálom elmondani, elmesélni, talán értelmezni is egy kicsit, ami nem jön elő az emlékezetből, azzal nem tudok mit kezdeni. 
Közben aztán más dilemma is adódik:

\section{Meditáció a mesélés nehézségeiröl}

Nem könnyü mesélni. Illetve nem könnyü mesélni akkor, ha nem ül velem szemben senki, akinek mesélnék. Akinek az arca, a szeme villanása visszajelezné, hogy érdekes-e amit mondok, érthető-e a mese, amit mondok, akinek a kérdéséből talán továbbindulhatna a mese. Amikor kézzel írtam, akkor ott volt elöttem a papír, kezemben a toll. Írtam a betűt, az rögtön megjelent a papíron, s akkor volt valami, tölem már tárgyiasultan elvált valami, amivel mégis valami kapcsolatom volt. Ott volt a betü, amit el lehetett olvasni. Ott volt a szó, ami jelentett valamit, s ha újraolvastam két sorral följebb, akkor 'jelzett' nekem, valami más volt már, ami nem én vagyok egészen, de mégis én, mert az én gondolatom van ott, de mégis más is volt már, mert le volt már írva, de jelzett, jelzett nekem, s kialakult egy kapcsolat köztünk. A papír, a toll és köztem. Még amikor a számítógépen írtam, akkor is. Ott is, ott van a kapcsolat a számítógép és köztem. Leütöm a klaviatúrán a betűket, megjelenik a képernyőn a szó, és amikor megjelent a képernyőn a szó, a mondat, és természetesen ott van a számítógép memóriájában ez a szó, ez a mondat, onnantól kezdve ez már nem én vagyok, az már tőlem elkülönböződött, kellően filozofikusan mondva, objektiválódott, és velem, mint tőlem különböző dolog, valamilyen kapcsolatban van. Én valamilyen kapcsolatba kerülök a géppel és a gépbe írt szöveggel, és mégis velem, külsöként önmagammal. A megkettőzött én!

Most, amikor csak egy magnetofon van a kezemben, és csak elképzelek legfeljebb valakit, aki hallgat, nincs kapcsolat. Magam vagyok. Nincs kapcsolat, mert a diktafon nem jelez vissza. Persze vissza lehet majd hallgatni, de most, amikor éppen mondom, nem látszik rajta, nem érződik rajta, hogy valami történt rajta, benne, a készülékben. Nehéz. Nehéz mesélni, ha nincs, kinek mesélj.

Nincs akinek mesélj? Így van? Vagy mégse egészen? Nézzük máshonnan!

Az író, regényíró, történetíró ül papírjával szemben és ír. És tudja, hogy most ő csak a papírjának ír. Csak a papírjával van kapcsolatban, de bízik abban, hogy majd valaki egyszer elolvassa. A mesélö a dolog lényegénél fogva mindig valakinek mesél. A mese, ami az élöszóban történő mesélést illeti, mindig egy mesélö és a mesét hallgatók viszonyában jön létre, alakul, formálódik. A mese eredetileg az élöszó müfaja, mégpedig az itt és most elhangzó élőszóé. Mesélni nem lehet másként, csak ha valakinek mesélek. Főleg ha az életemről, vagy a saját történeteimről van szó. Hogyan lehet átugrani ezt az árkot, ezt a feszültséget hogyan lehet feloldani? Nem tudom. De meg kell próbálnom, mert nincs, akinek meséljek, de mégis fontosnak tartom, hogy elmondjam a történetem. Kicsit magamért is. Magamért, hogy kibeszéljem magamból, és persze remélem azért azt is, hogy valahol valamikor, valaki másnak is jelenteni fog valamit ez a mese. A fiaimnak talán? Vagy tán másnak is? Nem tudom, de úgy érzem, hogy mesélnem kell és meg kell próbálnom magam elé képzelni valakit, akinek mesélek, mert másként nem lehet, és mert mást nem tudok, csak mesélni.

\section{A mesélés értelméröl, fontosságáról}

A Tao azt tanítja, hogy keresd meg a saját utadat. A saját utadat. Ne törődj mással, ne akarj mástól tanácsot kapni, és ne akarj másról példát venni. A saját utadat keresd. Mekkora az út, menynyire fontos, mennyire különbözik másoktól? $\mathrm{Ne}$ kérdezd. Csak a saját utadat keresd. Lehet, hogy ez az én mesém, amit most megpróbálok elmesélni, az is mond valaki számára valamit? Nem tudom. De nem szabad ezen gondolkozni. Nem szabad ezzel kínlódni. Nem az a dolgom, hogy azt méricskéljem, vajon fontos-e mások számára is, amit elmondok, vajon tudok-e olyasmit mondani, amit más még nem mondott el, vajon értelme van-e annak, hogy mesélek, nem szabad ezen gondolkozni. Az én dolgom azt hiszem most csak az, hogy meséljek. Nekem nincs tennivalóm azzal, hogy mi lesz ezekkel a mesékkel. Nekem csak azzal van dolgom, hogy elmeséljem őket, hogy közben rendbe tegyem magamat, ha tudom, és amennyire tudom... s a többi nem az én dolgom.

\section{Valamennyi a mesélésröl, a mesélés lélektanáról}

A kiinduló pontom az volt, hogy mesélni kell. Kell, ámbár nincs semmi külső kényszer. Nincs szerződésem, meg sem ígértem senkinek, hogy megcsinálom ezeket a meséket. Nem is nagyon tud róla azon kívül, aki leírta, senki, hogy csinálom. És mégis azt mondom, hogy kell. Mert van egy belső kényszer arra, hogy meséljek, a számvetés kényszere. A magammal történő számvetés kényszere. És ott van a belső kényszernek a másik fele: hogy mások számára, elsősorban természetesen a fiaim számára valamit tudassak arról, hogy ki vagyok én, hogy ki voltam én. Hogy nekik valamilyen 
értelemben legyenek gyökereik. Hogy ők legalább ebben a vonatkozásban ne maradjanak gyökértelenek úgy, mint ahogy én gyökértelen maradtam abban az értelemben is, hogy apám, anyám, nagyanyám nagyon-nagyon keveset meséltek nekem önmagukról, a gyerekkorukról, az életükről. Ami keveset tudok róluk, az nagyon kevés ahhoz, hogy valóban gyökereknek lehessen tekinteni. Azért kell tehát mesélnem, hogy a fiaimnak, ha egyáltalán valaha valamikor fontos lesz számukra, hogy honnan jönnek, milyen gyökerekből táplálkoznak azok az életerők, amik táplálják vagy táplálták, vagy elindították őket az úton, az életük útján. Ez a kettős belső kényszer az, ami rákényszerít arra, hogy meséljek. Amiért azt mondom, hogy mesélnem kell. Miközben időnként egyáltalán nem könnyü, mert ahhoz, hogy meséljek, ahhoz idő is kell, meg nagyjából megfelelő környezet is. De nemcsak ez korlátoz. Az is korlátoz a mesében, hogy a meséhez egy valamilyen lelkiállapotban kell lenni. Valami rákészülésben, valami belső nyitottságban, magamra való nyitottságban, és ez nem mindig van jelen, nem mindig áll elő.

Most éppen mintha lenne egy olyan állapotom, hogy tudok mesélni. Kinézek a fenyőfára az ablakon. Arra a fenyőfára, ami a szomszéd kertben áll, ami tehát ebben az értelemben nem az enyém, semmi közöm hozzá. De abban az értelemben viszont az enyém, hogy minden nap, ha kinézek az ablakon, látom. És látom az ágán a madarat is időnként. Enyémmé lett. De, és erre ma figyeltem föl, enyém a kukacvirág is. Van egy erkélyünk, egy pici erkélyünk. És annak az egyik oldalán van egy virágosláda. Még tavaly elültettem benne kukacvirágot. Elég szépen megnőtt, megvolt. Aztán ősszel elhervadt, elszáradt, úgy gondoltam, hogy ennyi volt. És idén tavasszal kinőtt, mert ez egy évelő növény mégiscsak. Kinőtt, s én elkezdtem öntözni szorgosan, s a nyár közepén virágba borult. Apró kis virágok, színes virágok, nekem nagyon tetszenek. Még most is, bár már hervadóban, de megvannak a virágok. $S$ most, amikor a fenyőfámra néztem ki, ott láttam a szemem sarkában ezeket a virágokat is, a kukacvirágot. És ez már az enyém. Mert én ültettem tavaly. Én locsolgattam idén, én nevelgettem. Ez már az enyém. Akkor mégiscsak van valami itt, ami az enyém. Van. És valószínűleg az, hogy van valami, ami az enyém, ami hozzám tartozik, ez segít abban, hogy tudjak mesélni. Segít abban, hogy össze tudjam szedni a gondolataimat, segít abban, hogy fel tudjak, fel merjek, fel bírjak idézni olyan korábban volt dolgokat, amik fájnak, amik nehezen felidézhetők, amikkel nehezen tudok belül boldogulni.
Lehet, hogy a kukacvirágnak olyan ereje van, ami megmozdítja az embert? Belül megmozdítja az embert? Vagy inkább a kukacvirágnak az a tulajdonsága, hogy az enyém, az mozdítja meg? Talán az utóbbi. Mindenesetre megmozdítja. Mindenesetre lehetővé teszi, belül lehetővé teszi nekem, hogy meséljek tovább.

Meditáció a magammal való szembenézésröl (meg a fenyöfákról) ((Az elözö folytatása))

Ülök a dívány sarkában, most magam vagyok szemben magammal. Ami ugyebár lehetetlen. Hiszen ha szemben ülnék magammal, akkor ketten lennénk. És én csak egy vagyok. Mégis szokták mondogatni, hogy az embernek időnként szembe kell nézni önmagával. Hogy lehet szembenézni önmagammal, ha egyedül vagyok? Mindenesetre az ember, ha magában van, akkor megpróbálhat magáról gondolkozni, és hátha ez vezet valamire. Kellő bizonytalansággal persze, mert hiszen minden szemlélés, akármit nézek, valamiképpen befolyásolt minden eddigi tudásomtól, élményemtől. Nem tudok teljesen elfogulatlanul, tisztán, tárgyiasan ránézni egy fenyőfára sem, még kevésbé egy tollra vagy effélére, mindig bennem van az, hogy eddig mit láttam. Ha egy fenyőfát nézek, sok ezer fenyőfa, amit valaha életemben láttam, visszaköszön. És befolyásolja azt, hogy most milyennek látom. Ha szép a rügye, akkor arra gondolok, hogy máskor milyen rügyeket láttam, azokkal összehasonlítva tartom szépnek, fejlettnek, vagy nem szépnek, nem fejlettnek. Bármit tekintek tehát, mindig ott vannak benne az összes elözö tapasztalataim, s ezek befolyásolják azt is, hogy akkor, abban a pillanatban éppen mit látok, hogyan látok, mit veszek észre, mit nem veszek észre.

Így van ez akkor is, hogyha magammal nézek szembe. Nem tudok teljesen tárgyilagosan szemlélődni akkor sem, ha magamat szemlélem. Elfogult leszek magammal szemben. Ez természetes. Említettem már, most újra mondom, akkor hát nem arról lesz szó ebben a memoárban, hogy milyen voltam, hanem arról lesz szó, hogy milyennek látom most magamat. Mire merek, mire tudok most emlékezni. Korlát ez? Hát persze, hogy az. Az emberi emlékezet, az emberi gondolkodás, az emberi személyiség korlátja. Nem tudom kiküszöbölni, legfeljebb tudomásul venni. És akkor ne keressünk az elmondandók mögött igazságot, valóságot, ne keressünk mögötte valami tárgyilagos elbeszélést, vegyük úgy, hogy én, most, igy látom. 
Például a fenyőt, ami az ablakunk előtt van. Mielőtt elkezdtem ezt a mesét, kinéztem az ablakon, a szemben lévő kertben ott van egy gyönyörű hatalmas fenyőfa, pontosabban kettő. Isten igazából semmi közöm hozzájuk, sem abban az értelemben, hogy nem a mi kertünkben állnak, kerítés választ el tőlük, sem abban az értelemben, hogy én ültettem volna őket vagy valami közöm lenne ahhoz, hogy vannak. És mégis ezek a fenyők számomra fontosak, talán mert szépek. Ha kinézek az ablakon, ezeket látom. S látom, hogy most tavasszal kezdenek kibújni az ágak végén a kis rügyecskék, amelyekből újabb ágak lesznek majd, amelyek az értő szemnek pontosan megmutatják, hogy mennyi idős az adott fenyő, ágak, amelyekre majd madarak ülhetnek rá csivitelni; ilyenek is vannak persze a szomszéd fenyőfán, most is ott ül egy harkály, billegteti a farkát... Dehogy harkály! Szarka. Billegteti a farkát. Sokszor-sokszor látom ezt a szarkát is. Valahol itt fészkel a közelben. Ez is hozzám tartozik már egy kicsit. $S$ nézem ezt a fenyőt, öreg jószág lehet, sok tízéves talán? S arra gondolok, vajon mekkora lehet az a fenyő, amit én ültettem el.

Mert harminc évvel ezelött - igen, most már harminc éve ennek -, Tahitótfaluban a telkünkön elültettem egy fenyőt. A Balaton-felvidékről hoztam, közönséges erdei fenyő, nagyon szépen megfogant, megfogott, és elkezdett nőni-növekedni. A végén már - mármint annak az időszaknak a végén, amíg miénk volt a telek - olyan jó három méteres lehetett és nagyon szépen növekedett tovább. Vajon most mekkora lehet? Mekkora lehet az a fenyő, amit én ültettem el, amihez nekem közöm volt? Amely fenyő a létét, pontosabban az ottlétét, hiszen a létét annak köszönheti, hogy valahol a Balaton-felvidéken egyszer elhullott egy mag, s abból kinőtt egy kicsi kis fenyőpalánta, amit olyan harminc-negyven centis korában, talán két éves, ha lehetett, gondosan körülástam, hátizsákba tettem földlabdával együtt és elhoztam Tahitótfaluba, szóval létét a Balaton-felvidéknek köszönheti. De az ottlétét, meg azt, hogy aztán megnövekedhetett, azt már nekem köszönhette. Hiszen ha száraz volt, akkor öntöztem, mellőle a gyomokat, amik esetleg veszélyeztették volna, kikapáltam, kiszedtem. És most már tőlem teljesen függetlenül létezik, ha létezik. Ezt sem tudhatom. Elültettem egy fát, gondoztam, ameddig módom volt rá, hogy gondozzam, aztán elkerültem onnan, s elkerült tőlem az a fa. Mekkora lehet? Vajon ülnek-e az ágán most is madarak? Enynyi marad belőlünk? Ha marad. Vagy ennyi marad utánunk, ha marad?
Ennyit a fenyőfáról.

Vagy ez már nem is csak a fenyőfáról szól? ...

Talán; gondolkozzunk el rajta...

Most lépek tovább, egészen másfelé. Vagy mégsem annyira más irány ez? Meglátjuk.

\section{Meditáció az egy ember élete „múltjának kútjáról”}

Megint ülök a dívány sarkában, s mögöttem, bár az ablakkal tőlem elválasztva, de mégiscsak ott van a már többször emlegetett fenyőfa. Fenyőfám. Mily groteszk is ez a birtokos személyrag megjelölés. Fenyőfámnak mondom, holott nem az enyém. Nem az enyém kétszeresen is, hisz nem én ültettem, és nem is az én általam lakott ház udvarán áll. Tehát mindenképpen tulajdonjogilag, akárhogy tekintjük, másé. S mégis azt mondom, fenyőfám. Az enyém. Mert valahányszor eljövök errefelé, a szoba másik feléből, kitekintek az ablakon, s látom a fenyőfát, $s$ magamévá teszem. A látványt. $S$ ezáltal, hogy a látványt magamévá tettem, valami sajátos módon enyém lesz ez a fenyőfa.

Mi az enyém, és mi a másé? Az-e az enyém, amit tulajdonjogilag enyémnek tekint a jog, s a törvény? Nem fontosabb-e, hogy ha rátekintek, magamévá teszem. S ez által az enyém lesz. Ott van tehát a fenyőfa, mögöttem, az én fenyofám, nem tudom, hogy meddig az enyém, ameddig itt lakom, $s$ hogy meddig lakom itt azt sem tudom, de most ott van, és most az enyém, és ez valamiképpen nyilván meghatározza gondolkodásomat is. Azt is, hogy miként gondolkozom a lakásomról, a helyről, ahol élek, mert hiszen ott van a fenyőfám, ami egy gyönyörü, hatalmas jószág, s függetlenül attól, hogy tulajdonilag enyém vagy sem, napi életemnek részévé lesz. Megint kérdések, amelyekre nem tudom a választ, vagy nem is akarom keresni, hiszen nem feltétlenül az a dolgom, hogy pontosan meghatározzam a jó választ. $\mathrm{Az}$ a dolgom, hogy kérdéseket tegyek fel, az a dolgom, hogy a kérdések segítségével magamat próbáljam megérteni, azt, hogy nekem milyen a viszonyom, a kapcsolatom a fenyőfával, a meleggel, napfénnyel, a kutyával, aki itt liheg a lábam mellett, mert valamiképpen ezek a fontosak, ezek, amik meghatározzák, befolyásolják az életemet.

Mostanában újraolvasom Thomas Mann József és testvérei című regényét. Ezzel a mondattal kezdődik: „Mélységes mély a múltnak kútja. $\mathrm{Ne}$ mondjuk inkább feneketlennek?” S majd ezt követően hosszú-hosszú oldalakon keresztül elmélkedik a múltról, arról, hogy a múlt hogyan épül be 
a jelenbe. Minden, ami megtörtént - valóságosan vagy a mítoszokban, ez szerinte teljesen mindegy -, hogy ami megtörtént, az ismétlődik, újraalkotódik a jelenben a múlt, egybecseng, egybefolyik jelen és múlt. A társadalom, egy törzs, egy embercsoport a maga múltját keresi, s megfogalmazza regékben, mítoszokban, más társadalmak, más törzsek, más emberek regéiben, mítoszaiban, múltjában keresve a párhuzamokat. Keresve, nem keresve, természetes módon ott rejtőznek ezek a párhuzamok. Ott vannak ezekben a különböző regékben, mítoszokban. $S$ ezekből épül fel egy emberi társadalom emlékezete. Az a valami, amit akár kollektív emlékezetnek is nevezhetünk.

De nem hasonlóképpen müködik-e az egyén, az egyéni ember emlékezete? Az, amit én ma gondolok a múltamról, a saját múltamról, amit megéltem, ami az én életidőmben történt, vajon az, amit én erről most gondolok, mennyire azonos, vagy mennyire nem azonos, mennyire hasonlít, vagy nem hasonlít arra, amit akkor gondoltam a dolgokról, amikor éppen történtek? Vajon a történések ideje és egymásutánja nem arról szól-e, hogy a saját életemben is, a saját múltamban is a megtörténteket, az egyszer valaha régen megtörténteket átszínezi, átfesti a későbbi történet, amit később megéltem. Nem arról van-e szó, hogy amikor egy korábbi, régmúlt, a saját életemben régmúlt kapcsolatról gondolkozom, akkor rávetítem későbbi hasonló kapcsolataim történéseit. Nem arról van-e szó, ahogy amikor most arról gondolkozom, hogy tíz, húsz, negyven, ötven évvel ezelőtt mi történt velem, akkor valójában nem tudom azt elmesélni, hogy mi történt velem, csak azt tudom elmesélni, hogy most mit gondolok arról, hogy mi történt velem? Biztos, hogy ez ugyanaz? Lehet, hogy, azt kell biztosra mondanom, hogy nem ugyanaz. Amit ma gondolok korábbi önmagamról, abban benne van az, hogy ma mit gondolok önmagamról. Amit ma gondolok arról, hogy mit miért és hogyan tettem vagy nem tettem tíz, húsz, negyven, ötven évvel ezelött, az nem az, amit tényleg tettem, hanem az, hogy amivé lettem, ez az ember, ez a valaki, ez a személyiség, aki ma vagyok, hogyan gondolkozik arról, aki tíz, húsz, ötven évvel ezelőtt voltam. Lehetséges-e tehát valóságos emlékezés? Lehetséges-e tehát régen múlt, saját életemben régen múlt dolgok biztonságos felidézése?

És itt nemcsak arról van szó, hogy az emlékezet torzít. Hanem arról van szó, hogy közben, az elmúlt tíz, húsz, ötven év alatt én változtam sokat. Bennem történt sok minden. Persze annak hatására, azzal együtt, hogy velem történt sok minden. De bennem is történt sok minden. Más értékek szerint gondolkozom, bizonyos értelemben, mint tíz, húsz, ötven évvel ezelőtt. Vannak persze az értékeknek azonosságai. Van, ami állandóan ott volt, legalábbis reményeim szerint mindig, a gondolkodásomban, bizonyos alapvető dolgok, de sok és nagyon sok más dologról másként gondolkozom, mint tíz, húsz, ötven évvel ezelőtt. És akkor vajon ez a másként gondolkodás nem befolyásolja-e az emlékezést, a történésekre való emlékezést? Biztosan. Biztosan befolyásolja. Amikor tehát most a múltamról, valamikor volt magamról mesélek, akkor egyszerre ott van az egy olyan emlékezés, amikor megkísérlem felidézni, előhívni azt az embert, aki valaha voltam. De már maga a felidézés folyamata is befolyásolódik azzal, aki ma vagyok. Mennyire hiteles tehát az, amit a múltamról elmondok? Mennyire biztos? Semennyire.

Ahogy elkezdtem ezeket a meséket leírni, sokszor voltam úgy, hogy rögzítettem valamit, s aztán másnap vagy harmadnap újragondolva, újrahallgatva rá kellett jönnöm, hogy nem pontosan úgy történt, mert magam mentéséért, azért, hogy valamiképpen mégis harmóniában legyen az ötven évvel ezelötti énem a jelenlegivel, átszínezem a múlt történéseit is.

Mit tehetünk? A magunk élete is, a magunk múltja is bizonyos értelemben mélységes mély. $A$ magunk múltjának kútját is „Ne mondjuk inkább feneketlennek?” Olyannak, aminek nem tudunk elérni a fenekére, vagyis nem tudunk valami biztosat arról, hogy milyen mély és mi van ott lent a mélységben? Éltem az életemet, nevezhetjük ezt az én életidömnek. Ez önmagában sem olyan egyszerủ dolog: mi benne a lényeges - tehát elmesélendő - történés, és mi a felejthető, a lényegtelen; nem könnyű eldönteni. De még bonyolultabbá teszi a dolgot, hogy nem vagyok egyedül. Bár „külön világot alkotok magam”, mégis tudni kell, hogy „hiába fürösztöd önmagadban, csak másban moshatod meg arcodat”. Tehát az idő, az én időm, egy dolog. De azok, akikkel kapcsolatba kerültem, barátaim, szerelmeim, mások, nekik is megvan a maguk ideje. S vajon ez a kétfajta idö; az én idóm s az ö idejük egyformán múlik-e? Hogy amikor én arról beszélek, hogy egyikkel, másikkal, harmadikkal, holtakkal vagy nem holtakkal, akik elö-elösorakoznak a múltból, hogy róluk, amikor elmesélek ezt vagy azt, az én időm szerint mesélvén el ezt, vajon az ő idejük ugyanezt jelenti-e? Amikor én azt mondom egy valaha volt barátomról, hogy barátom volt, aztán elmúlt, egyszerűen csak elmúlt ez a barátság, ez az 
én időm szerinti megfogalmazás. Az én időmben ez történt. Ez volt az én idöm tartalma. Vajon az övé azonos-e? Hasonlít-e? A barátságunk idejét ő is barátságunk idejének érzékelte-e, érzékeli-e, ha emlékszik, ha visszagondol, vajon ő is barátságnak gondolja-e? S az elmúlást, a barátság elmúlását, vajon ő is, hozzám hasonlóan csak egy eltünésnek, elhomályosulásnak érzékeli-e, vagy netán ő árulásnak érzi? A barátságunk elárulásának? Az ő ideje szempontjából ez fontos, kitüntetett pillanat-e? Nem tudhatom, mert ez sohase beszélhető meg, hiszen elmúlt ez a barátság. Elmúlt ez a kapcsolat, elmúlt ez a viszony. Talán már nem is él, akiről szó lehetne. Nem lehet összehangolni az időinket. Mindenkinek megvan a maga életideje. A maga életének a ritmusa, a tartalma annak, amit megél, s ez a tartalom persze mindig sokféle egyszerre. Hiszen abban az időben, amikor egy barátságról beszélek vagy barátságról gondolkozom, egyidejűen nekem is nagyon sokféle más dolgom is történt a saját időmben, a saját életemben. Más barátság, más kapcsolat, szerelem, akármi, nemcsak ő volt jelen. Honnan tudhatnám hát, hogy neki mit jelentett, az ő ideje szempontjából mit jelentett az az idő, amit velem töltött? Tartalmas volt, fontos volt? A maga szempontjából őt építő idő volt? Vagy csak egyszerűen elmúlt számára? Egy nem fontos történés volt? Nem tudhatom. És innentől kezdve azt se tudhatom, hogy végső fokon és végtére, nekem mennyire volt fontos ez az idő. Az az idő, amit az ő barátságában tölthettem. Vagy szerelmében, vagy más kapcsolatunkban; itt most teljesen mindegy, hogy miféle viszonyról volt szó. Az időértékelésnek a különbözősége mindre egyformán érvényes. Melyik tartalma tehát az időnek, ami elmesélendöen lényeges? Eldönthetetlen.

És mégis, nem tehetek mást, meg kell próbálnom mondani a dolgokat, mesélni a magam ideje szerint, ahogyan én megéltem, nincs más megoldás. Nem tudok kilépni önmagamból, nem tudok átlépni másokba, nem tudom átélni a más idejét, csak a magam szempontjából tudom nézni a dolgokat. $S$ a magam szempontjából ez most éppen azt jelenti, hogy abból a szempontból, abból a pozícióból, abból a helyzetből, abból az állapotból, amiben $m a$ vagyok. Ha ez így van, akkor ez legalább rész szerint felment az alól a felelősség alól, ami azokkal szemben áll fent, akikről beszélek. Hiszen az, amit én elmondok, az az én igazságom. Ha én azt igazságnak gondolom. Néha ez is kérdéses. De mindenképpen az enyém. És csak az enyém. S neki is, akiről beszélek, adott esetben, megvan a maga igazsága.
Amit ő megélt, ahogyan ő megélte azt, amit együtt megéltünk, ahogyan ő feldolgozta és felfogta azt, ahogyan, amit együtt megéltünk. Hogy eltér-e az ő igazsága az én igazságomtól, persze kérdés. De nem fontos kérdés. Mert mind a kettő valamiképpen igazság. Az enyém azért, mert én így éltem meg, és így rakódott le bennem mindaz, ami történt, az övé azért, mert ő valamiképpen megélte és benne valamiképpen lerakódott az, ami történt. Hogy mi a tulajdonképpeni igazság, hogy mi történt valójában? Lehet, hogy eldönthetetlen, hiszen különbözőek vagyunk, akik ugyanazt a dolgot, ugyanazt a történéssort másként éljük meg, másként hat ránk, múltunkból s egyebekből következően másként hat ránk, és innentől kezdve azokban a dolgokban, hogy én szerettem, nem szerettem, elhagytam, nem hagytam el, ő hagyott el, én hagytam el, ezekben a dolgokban nincs abszolút igazság. Én nem tehetek mást, mondom a magamét.

\section{Még egy meditáció a "múltnak kútja” kimerithe- tetlen elmondhatatlanságáról}

Megint Thomas Mannt veszem elő. „Mélységes mély a múltnak kútja”. Thomas Mann is jól tudja, hogy a múlt csak az emlékezet, az elbeszélés szempontjából tűnik feneketlennek, a valóságos időben nyilvánvalóan nem feneketlen, vagyis végtelen, hanem nagyon is véges idő történéseiről van szó. Ámde a feneketlen múlt mégis feneketlen kút. Mert az emlékezet, és így az elbeszélés sem képes a feledés homályába tünt történések mindegyikéről, amelyek azonban lehet, hogy lényegesek volnának a megértéshez, nem képes mindezekről számot adni. Így ír. Idézem hosszan: „Mert éppen ekkor történik az, hogy minél mélyebben fürkészünk, minél mélyebbre hatolunk és tapogatózunk a múlt alvilágába, az emberinek, történetének, művelődésének kezdeti alapjai tökéletesen megmérhetetlennek bizonyulnak, s mérőónunk elől bármily kalandos távolságokba gombolyítjuk alá zsinegét, mindig újra és tovább húzódnak vissza a feneketlenségbe. Találóan mondhatjuk itt, hogy újra és tovább, mert kutató buzgalmunkkal a kikutathatatlan incselkedő játékot űz. Látszatmegállókat és úti célokat kínál, melyek mögött, amint elértük őket, újabb múltszakaszok tárulnak föl”. ${ }^{1}$ Így van ez, azt gondolom, az egyetlen ember emlékeiről beszámoló elbeszélővel is. Elmondhatatlanul sok a történet, a feledés is müködik, s mint tudjuk,

1 Thomas Mann: József és testvérei. Előjáték: Pokolraszállás. Budapest, Park kiadó, 1993:6. https:// mek.oszk.hu/03600/03655 
korántsem csak a nem fontosakat törli. Sőt. Az egyes ember élete is éppoly mélységes mély, vagy ha nem is oly mély, ha mélységnek az időt, a történések idejét tekintjük, de éppúgy kimeríthetetlen. Akarod elmesélni? Nem lehet. Ha mindent elmondanál, ami történt veled és benned, az elmondás ideje még az is lehet, hogy több volna, vagy ugyanannyi; mindenesetre alig kevesebb, mint a történések ideje. Mondhatnók, vannak történés nélküli idők is, például amikor alszunk. De az álmok vajon nem tartoznak-e a történések közé? Nem rólad szólnak-e? S milyen nehéz elmesélni az álmokat, mennyi rengeteg szó kell ahhoz. Hiú vágy volna hát, ha meggondolatlanul az időben telő történések és azok elmondására szükséges szavak elmondása idejének sajátságainak figyelmen kívül hagyásával egy élet teljes történetét akarnád elmesélni. Nem lehetséges. Mélységes mély a múltnak kútja, és mélységes mély az egyes ember életének kútja is, legalábbis abban az értelemben, hogy kimeríthetetlen, kimerhetetlen kút. Nem tehetünk mást, mozaikokat gyüjtögetünk össze. Tudván, a szinte végtelenül sok apró kocka elenyésző töredékét tudjuk emlékezetünk, egyébként is tudjuk, sok okból hiányos, feneketlen kútjából elmondó mesénk napvilágába emelni. Légy szerény! Mondom magamnak. Elégedj meg a mozaikokkal, amelyek gyakran bizony inkább csak törmelékek. És mutasd meg, vagy talán olykor némelyiket mutasd fel. Mint áldozati ajándékot mutatott fel a sámán vagy a föpap az isten ünnepén, tartsd a megismerő fény felé, és bízzál, reménykedj a felmutatottat megnéző megbocsátó megértésében. Aki, a megnéző, talán majd helyére is teszi a törmeléket mozaikdarabként, vagy, ez már az ő dolga, feleslegesként félredobja. Az én dolgom nem lehet más és több, mint a meg- vagy felmutatás.

$A$ „Mesélek magamról” egyik része az „Asszonyok, lányok, szerelmek I." alcimet kapta. Ennek „,bevezetése" az itt következö töprengés, ami - úgy mellesleg - az érzések megfogalmazhatatlanságáról is szól, meg arról, hogy mit szabad elmondanom róluk.

Napok óta készülődöm már arra, hogy elkezdjem ezt a történetet. Nem most kezdtem a „készülődést”. Hosszú-hosszú, évekre visszanyúló története van annak, hogy gondolkozom, megpróbálom magamat megfejteni, milyen is a viszonyom, milyen volt a viszonyom asszonyokhoz, lányokhoz, szerelmekhez. Nagyon, nagyon fontosak voltak nekem. Készülődtem hát, és próbáltam megfelelö mondatokat keresni. Mondatokat, szavakat, és ha mondatokat, szavakat, akkor fogalmakat. Holott, ha valamihez, ehhez, az asszonyokhoz, nőkhöz, szerelemhez való viszonyról nagyon nehéz fogalmakban beszélni. Ahogy készülődtem, talán nemcsak most, hanem évekkel, évtizeddel ezelőtt is, amikor erről gondolkoztam és megpróbáltam sokszor, sokszor végiggondolni, hogy hogyan is voltam én ezekkel a kapcsolatokkal, hogyan voltam bennük, s hogyan hatottak rám, soha nem szavakban, fogalmakban gondolkoztam. Képek villantak elém. Hol homályos, hol kristálytiszta képek. Képek villantak, mondom, mert csak egy-egy fel-felbukkanó kép, egy-egy emléktöredék jutott el a megformálódásig. Képek, emléktöredékek és érzések, hangulatok emléke. Érzéseké, hangulatoké, képeké. És mindezeknek az emléke csupán. Hiszen nem éltem újra az érzéseket és hangulatokat, nem élhettem újra: most, 78 éves koromban nem tudok úgy érezni, és nem tudom azt a hangulatot átélni, amit húsz, harminc, negyven évvel ezelött éreztem. Emlékszem a képre, a hangulatra, érzésre, és meg kell próbálnom ezeknek az emlékeknek, a képeknek, hangulatoknak, érzéseknek az emlékét szavakban megformálni.

Önmagában is egy kép, egy hangulat szavakban való megformálása pokolian nehéz. Hiszen egy más természetű közegbe kell átemelni a dolgokat. Az érzelem az érzelem. Fogalmakkal nem megragadható igazából. Meg lehet próbálni szavakba önteni, meg lehet próbálni érzékeltetni mással, hogy mi volt ez az érzés, mi volt ez a hangulat. De ez már mindenképpen egy tükrözödés. Egy forditás. Leforditom az érzést a fogalmak világára, más természetủ világba. A fogalmak mindig általánosak, ridegek, szerkesztettek, és mindig más által megfogalmazott, más által kikristályositott szerkezetek. Más által persze, mert hiszen nyelvben beszélek, magyarul. A magyar nyelvet évszázadok fejlődése alakította olyanná, amilyenné. Ezrek és százezrek gondolati munkája van benne, hogy egy fogalom valamilyen tartalmat nyerjen. És a nyelv mindig absztrakció, mindig valami elvont, elvonatkoztatás. Az érzés pedig, a hangulat, az mindig a pillanathoz kötött. Mindig egy pillanatnak van érzelmi töltete, mindig egy pillanatnak van valóságos jelenléte, a fogalom az mindig valami nem valóságos. Az érzés egyszeri és egyedi. Hogyan lehet ezt a fordítást, ezt az egyik, mondjuk úgy, létminőségből egy másik létminőségbe, az érzelmi létminőségből a fogalmak, az absztrakciók létminőségébe való átfordítást megtenni? Iszonyú nehéz. Iszonyú nehéz főleg akkor, ha a saját érzésemröl van szó. Amiről én tudom, hogy micsoda. És azt akarom, azért fogalmazom meg, hogy más is tudja. De vajon, aki azt a mondatot olvassa vagy hallgatja, abban, aki azokat 
a fogalmakat megérti, átgondolja, vajon ugyanaz az érzés jelenik-e meg, amit én éreztem? Azt hiszem, sohasem. Hiszen ugyanazon a fogalmon mindanynyian egy picit mást értünk, mindannyian másfajta jelentéstartománnyal használjuk azt. Lefordítjuk önmagunkra. Akkor hát átadhatatlan az érzés? Megfogalmazhatatlan? Igen. Átadhatatlan és megfogalmazhatatlan. Csak jelzésekre van módunk.

Ezzel kínlódom napok óta. Hogy ezeket a jelzéseket hogyan lehet formába önteni.

És akkor ott van, második csavarnak, hogy nem a pillanatnyi érzésemet akarom fogalmazni, hanem az érzés, a hangulat emlékét. Az érzés, a hangulat, ami volt, megvolt, valamikor, egy adott pillanatban. Húsz, harminc, ötven évvel ezelőtt. Amikor most erre a valaha voltra visszaemlékszem, természetesen nem ugyanazt érzem. Az érzés emléke van bennem. És ebben az emlékben benne van az azóta megélt életem, módositja ezt az érzés-emléket, hiszen ezeknek az érzéseknek, hangulatoknak, szerelmeknek az életemben is volt egy utóélete. Beteljesült vagy nem teljesült be, így lett vége vagy úgy lett vége, ami már eleve módosította az érzésre való emlékezést. És most, amikor sok év vagy évtized után megint visszaemlékszem ezekre az érzésekre és hangulatokra, még inkább torzulnak. Igazából persze nem tudom, hogy ez torzulás-e? Atértékelödnek vagy átszinezödnek mindazzal, amit megéltem. Torzulás ez? Vagy talán gazdagodó módosulás? Ki tudja? ...Többszörös tükröződés, többszörös torzítási lehetőség. S mégis meg kell próbálni. Meg kell, mert az asszonyok, lányok, szerelmek, voltak volt azok valóságosak vagy csak elképzeltek, mindenképpen az életemnek egy nagyon-nagyon fontos részét alkották. $S$ tulajdonképpen alkotják ma is.

Készülődtem tehát, kerestem a szavakat, mondatokat, amelyekkel valahogy mégis meg lehet közelíteni ezeket az emlékeket, képeket, érzéseket, hangulatokat. Nem tudom, hogy megtaláltam-e a szükséges mondatokat. Egyáltalán nem vagyok benne biztos.

És még egy kemény, morális dilemma.

Borzasztó nehéz a nőkről, az asszonyokról, a szerelmekről mesélni, és nemcsak azért nehéz, mert nagyon bennem vannak, nagyon mélyen bennem élnek, nagyon mélyről kell tehát felhozni és formába önteni, a szavak formájába önteni azt, amit szóformába önteni lehetetlen, nemcsak ezért nehéz. Hanem azért is, mert nekem alig vannak halottaim. Akikről én mesélek, akik hol homályos, hol éles képekben előttem elvonulnak, akik hol homályos, hol egy-egy éles pillanatkép rögzültségében megjelennek előttem, egy-egy helyzetben, egy-egy szituációban, ők, azt hiszem, többségükben, élnek.

Élnek, élik a maguk immár tőlem teljesen független életüket, vannak más kapcsolataik, férjük, szerelmük, akárkik, gyerekeik, mit mondhatok el róluk? Mit mondhatok el róluk úgy, hogy ne sértsem, ne bántsam őket? Hogy ne sértsem, bántsam, vagy ne tegyem félreérhetővé életüknek azt a pillanatát, szakaszát, amikor velem voltak, velem kapcsolatban voltak. Mit mondhatok el úgy, hogy az, akivel valaha kapcsolatban voltam, nyugodtan és lelkiismeret-furdalás nélkül odatehesse gyerekei elé azt a képet, amit én megfestek vagy leírok róla. Iszonyúan nehéz. Mert el kell mondanom sok mindent, amiről tudom, hogy nem lenne jó nekik, ha ezt más is hallaná, olvasná vagy tudna róla. Mert tudom, hogy nekik is, mint mindenkinek a világon, vannak titkaik, amiket meg kell őrizni. Amiket nem lehet, nem szabad kiadni. Talán önmaga elött sem, de mások előtt bizonyosan nem akarnák föltárni ezeket a titkokat. És lehet, nem tudhatom, ezek közé a titkok közé valamiért - és fogalmam sem lehet róla, hogy miért - oda tartozik-e a velem való kapcsolatuk, vagy annak egy része is. És akkor hogy jövök hozzá én, hogy egy akár csak apró kis lebbenésükről is elmondjak valamit, felszínre hozzam azt a titkot, amit ők nem akarnának felszínre hozni? De ha én magamat meg akarom érteni, ha én magamat meg akarom mutatni, miért olyan vagyok, amilyen, ha meg akarom mutatni, hogy hogyan lettem olyanná, amilyenné lettem, akkor nem lehet nem beszélni róluk, és arról a hatásról, amit rám tettek. Hogyan lehet megoldani azt, hogy elmondjak mindent, ami fontos ahhoz, hogy én milyen vagyok, ami fontos ahhoz, hogy engem megértsem (én, magamat) és megértessem, hogy lehet mindezt elmondani úgy, hogy közben őket ne bántsam? Nem tudom, hogy fog-e sikerülni, ezt nem tudom. De valamit meg kell próbálni, mert mondtam, az életemnek nagyon nagy részben meghatározója az, hogy hogyan voltam nőkkel, asszonyokkal, lányokkal, szerelemmel, szexualitással, ez hozzám tartozik, és nagyon erősen hozzám tartozik, talán erősebben, mint másnál.

\section{Végtére is mi az, ami elmondható?}

Megint és újra elfog a bizonytalanság, mi az, ami elmondható, és mi az, aminek végképp és véglegesen titoknak, a lét titkának, a lélek titkának kell maradnia? A belső cenzor ágaskodván újra szerepre tör, követeli a maga helyét a gondolkodás és mesemondás folyamatában. 
Kimondható-e, amit mondani szándékozom, mások miatt? A másik miatt, akivel kapcsolatba kerültem, és akiről olykor és ebben a mesében szinte mindig másról is szól a mondat. Jogom van-e magamat keresvén, magamat akarván megmutatni, másokról elmondani azt, amit ők talán nem akarnának elmondani? Ha nem mondom, magam megmutatását csorbítom, netán lehetetlenné teszem. Ha mondom, bántom őket, vagy ami rosszabb; befolyásolom az ő másokkal való kapcsolatukat. Tehát beleavatkozom az életükbe. Valamiképp minden szóval, minden mondattal, amit másokról elmondunk, leírunk, beavatkozunk az életükbe, és mégis, ezek a szavak, mondatok, ha magamról mesélek, megkerülhetetlenek, hiszen életem meghatározó részét, ha nem az egészét, a másokhoz való viszonyaim teszik ki. És így minden magamról mondott szó másokról is szól. Egyszóval minden ilyen szó beavatkozás az életükbe. A kérdés tehát végső soron az: van-e jogom azzal, hogy mesélek róla, beleavatkozni másnak a saját, tán némely részében titoknak tartani akart életébe? Nincs jó válasz. Sőt egyáltalán nincs válasz.

Mondhatni, gyáván kibújok a válasz alól, és nem tehetvén mást, ezt teszem. Azzal, hogy reményeim szerint ízlésem és tapintatom majd eltűrhető kordában tart. Eltűrhetően nekem még éppen elég teret biztosítván mesém engem mutató dolgainak elmondásához, és eltűrhetően másoknak, épp csak annyira beavatkozva életükbe, ami még elviselhető. Gyenge és bizonytalan kibúvó, tudom. Mi lenne gyengébb s bizonytalanabb, mint ízlésre és tapintatra hivatkozni? Az ízlések tudjuk különbözők, a tapintatnak miféle mércéje lehet? Mégsem tehetek mást. A kérdésekkel másként nem tudok mit kezdeni. Nem szándékom bántani mást se, magamat se persze, csak szeretnék megérteni. Szándékom szerint annyit és csak annyit akarnék elmesélni, amire, ítéletem szerint feltétlenül szükség van.

Most valóban valami egészen másról:

\section{Meditáció az irásba foglalás sajátosságairól}

Nagyon nehezen tudom folytatni most a mesét. (A „most” persze megint több év előtti időpont.) Miért? Elmondom.

Meséim első része leírattatott. (Illetve, legyünk pontosak, egy nagyon kedves hölgy, neve ne maradjon említetlen: Urbán Beatrix írta számítógépen az eddigieket. Ezt, és a továbbiakat egy nem kevésbé kedves kolléganőm: Pócsikné Bornai Kamilla írta le. Köszönöm itt is nekik!) Ez mindjárt, fontoljuk meg, kettős jelentésű történés. Az egyik voltaképp számomra igen kevéssé átlátott, és ezért nekem igen kis jelentőségű történés, annyi, hogy mesémet ily módon átadatott az elektronikus, virtuális örökkévalóságnak. Mondják ugyanis a hozzáértők, hogy amit egyszer e-mailben elküldtek, és hozzám a szöveg így jutott el, az valahol, ki tudja hol, valami rejtélyes, mármint számomra rejtélyes szerveren ott marad. Nem törlődik le, hozzáértő hacker, ha nincs jobb dolga, bármikor előszedheti. Mondom: ez engem kevéssé érdekel, meglehetősen biztos lévén abban, hogy nem akad hacker, aki épp erre kíváncsi. Mert annyi fontosabb meghackelni való van. A másik jelentés annál fontosabb.

Mit jelent ugyanis az a megjelölés: leírattatott? Nem kevesebbet, minthogy a szöveg, mesém szövege átkerült egy más létminőségbe. Az élö szóból, amit csak a diktafon ôriz, az irott formában objektivált minőségbe. Igaz, állandó létszerűségében még mindig a digitális formában van, egy számítógép memóriájában és pen drive-on, de innen egyetlen kattintással előttem van a monitoron írott betűk formájában, bármikor kinyomtathatóan. A mese, ámbár a maga mese minőségében, de objektiválódott. Objektumként, tárgyként létezik, tőlem, a mesélőtől immár elkülönböződve éli a maga életét. Én természetesen még mindig dönthetek úgy, hogy letörlöm, ámbár szakértők szerint tökéletes törlés nemigen van. Bele is javíthatok, hozzáírhatok. Szóval bánhatok úgy vele, mint egy tulajdonomban lévő, és nekem kiszolgáltatott tárggyal. De már nem magamon dolgozom, hanem egy tôlem különbözö tárgyon. A leírás aktusával véglegesen és végletesen megváltozott az én viszonyom a meséhez. Ha már láttam leírva, amit elmeséltem, elmeséltem magamban, magamnak a diktafonba, onnantól kezdve másként fogok mesélni. Ha igyekszem is eltekinteni tőle, mégis, önkéntelenül, méghozzá kiküszöbölhetetlen önkéntelenséggel, ott lesz elöttem annak a képe, hogyan fog kinézni ez leírva. Jobb lesz ettől a mesélt, az elmondott szöveg? Rosszabb lesz? Nem tudom. Valamennyire más lesz. Hogy mennyire más, azt sem tudom.

És még valami, ez talán nekem minden bizonnyal a legfontosabb. Olvasom a leírt szöveget. Természetesen működésbe lép az itélöerő. Természetesen, mondom, hisz szakmámból - itt hozzáteszem, mert fontos: szakmáimból, lévén magyar szakot végezve kiképzett irodalmár is lennék -, szóval szakmáimból következően rászoktam, hogy minden elém került szöveget kritikusan tekintsek tartalmilag és megformáltságát tekintve is. Igaz-e, 
hihető-e a szöveg? (Legalábbis a saját belső logikája szerint). Megformáltságát tekintve pedig azt nézhetem, pontos-e, érthetö-e, valamilyen nagyon általános elvont értelemben szép-e. Ha szépség alatt az arányok megfelelőségét, a megválasztott szavak kifejezőerejét, a gondolatok érzékelhető ritmusát értem. Olvasom tehát meséim betűk álruhájába öltöztetett szövegét. És csalódom némiképp.

A tartalom nagyjából az, amit elmondani szándékoztam, eltekintve természetesen attól a sajnos megszüntethetetlen különbségből fakadó eltéréstől, hogy ugyanis a szó fogalom mivoltából származó lényegi sajátlagossága folytán, mindig csak korlátozottan, jó esetben közelítőleg tartalmazza és közvetíti az érzelmeket, ami a magamról mesélés belső törvényszerüsége következtében mindig kíséri, olykor megalapozza az éppen elmesélt tartalmat. Ettől eltekintve tehát a leírt szöveg tartalmával nagyjából elégedett lehetek, azt hiszem. Ámbár persze ebben is bizonytalan vagyok. Vajon a leírt tartalom valójában az-e, amit el akartam mesélni? Nem lehetséges-e, hogy csak én, aki meséltem, látom bele a szövegbe ezeket a tartalmakat? És más, aki netán és hiú reményeim szerint olvassa, egészen más, vagy éppen semmilyen tartalmat nem tud felfedezni? Ezt sem tudhatom, de ezzel nem kell foglalkoznom. A megformálás módja az, ami valamifajta csalódást okoz.

Amikor mondtam, még amikor visszahallgattam is, szebbnek, esztétikai értelemben is megformáltabbnak tűnt a szöveg. Talán azért is igyekszem mentálisan kötelező önvédelemből értékesebbnek feltüntetni magam, mert ahogyan mondtam a mesét, abban - színészvér - benne van az érzelem. Talán az is, ahogyan egy színész el tud adni egy gyengébb szöveget is. Ám bizonnyal nem ez a lényeg. A lényeg, ahogy ezt én most látom, megint kettős természetü. Az egyik felével könnyen végezhetnénk. Immáron a leírt szöveg kritikus megtekintése után végképp be kell látnom, amit eddig is nagyjából pontosan tudtam, hogy írói tehetségem meglehetősen korlátozott. Olvashatsz figyelemmel és tanulságkereséssel akármennyi Thomas Mannt, Déryt, attól még nem leszel jó író. Erről ennyit. A másik rész kissé bonyolultabb, és talán általánosabban is megfontolásra érdemes. Mintha az ember, aki épp dolgozik valamin, s e szempontból mindegy, hogy épp mesél-e, ír-e, vagy asztalt készít, képet fest, a tökéletesség, vagy legyünk szerényebbek, a jó minöség igényével teszi azt. $S$ amíg formálódik keze alatt az anyag - szó, vagy fa, vagy festék, mindegy -, addig dolgozni csak úgy tud, ha hisz abban, erős hittel, hogy jó az, amit csinál. Csak ha elkészült és szemügyre veszi, és van benne elegendő ítélő erő, veszi észbe, szavai nem mindig szépek, hogy az asztal lába kicsit ferde lett. Vajon törvényszerủ ez? Talán. Én mindenesetre így jártam.

\section{Újabb közbensö meditáció a leírásról}

Mert innentől kezdve más okból is nehézzé válik a mese. Egészen addig, míg csak ebben a szerkezetben volt jelen, amíg csak az én hangomon volt jelen, addig, még egyszer mondom, csak az enyém volt, titok volt, és addig, amíg ez így volt, addig csinálni gyönyörüség volt. Mert úgy érezhettem, hogy mondom, mondom, mondom különösebb megfontolás és felelősség nélkül mondom, jól esett mondani, olyankor mondtam, amikor éppen hangulatom volt hozzá. Attól a pillanattól kezdve, hogy megláttam leírva, hogy ott van, most már a számítógépben írásos formában, részben kinyomtatva és papíron, innentől kezdve valamiképpen úgy érzem, hogy feladat lett. Feladat, amit teljesítenem kell. Ez valami egészen más, mint egyszerűen csak mesélni. De mégis folytatnom kell a meséket. Folytatnom kell, mert az, amivel elkezdtem, amiről a legelején beszéltem, az, hogy számot kell adni önmagamról, számot kell vetni önmagammal, ez változatlanul érvényes. Ha feladat, akkor legyen feladat. Amit teljesítenem kell. Innentől kezdve így is folytatnom kell a meséket.

És akkor a végsö (gnoszeológiai lismeretelméletil és morális) kérdés: mi az, amit el kell és lehet mondani; mi a fontos és mi nem?

Villannak még emlékmorzsák, és nem tudom eldönteni, vajon rögzítésük szükséges-e. Kell-e ahhoz, hogy én jobban megértsem magamat, és más, aki olvassa - ha lesz, aki olvassa - jobban megértsen engem. Ha úgy vélekedem, és miért ne vélekednék úgy, hiszen minden okos megfontolás efelé a vélekedés felé taszítja a gondolkodásom, hogy minden történés, a legkisebb is, az is például, hogy hogyan köszönt vagy nem köszönt a boltban a pénztáros, formál engem valamicskét, alakít rajtam egy hangyányit, belém épül. Minden apró történés egy pici mozaikkocka, része annak az egésznek, ami vagyok. Már amennyiben és amilyen mértékben a szó igazi értelmében egésznek tekinthető az, ami vagyok. Bizonyos értelemben igen, mivel vagyok. Mindenképpen a világ egy jól elkülönült, és elég pontosan, legalábbis külsőleg elég pontosan definiálható része. És ebben az értelemben mások, nemigen tehetvén mást, egy bizonyos egésznek tekintenek. 
De lényegi, tartalmi értelemben bizonyosan nem vagyok egész, már csak azért sem, mert az egész mivolt valami teljességet, valami befejezettséget jelent. És én, amíg sejtjeim életjelenségeket mutatnak, és amíg többé-kevésbé ép elmével veszem tudomásul az engem érő hatásokat, és reagálok, kívül-belül reagálok azokra, addig szükségképpen változom, tehát nem lehetek befejezett és egész. A kérdés tehát úgy módosul, vajon annak a félig-meddig kész valaminek, ami most vagyok, a megértéséhez szükségesek-e az emléknyom-villanások. Ha igen, melyik igen, melyik mellőzhető? Vagyis mi lehet a mérce a lényeges-lényegtelen kérdésének eldöntésében. Mélységes sajnálatomra be kell látnom, hogy nem tudok ilyen mércét.

Vajon az a majd' ötven évvel ezelőtti szilveszteri történés, amikor még Mosonmagyaróváron egy baráti társaságban mulatozva vártuk az új évet, közben persze táncoltunk is, és a tánc közben egy számomra sem ellenszenves asszony, aki egyébként épp akkor volt válófélben, félre nem érthetően, jelzésértékűen hozzám simult, és én e simulást jólesően elfogadtam, miközben feleségem a másik szobában másokkal trécselt, vajon ez a mikrotörténés, időtartamát tekintve legfeljebb fél perc, és folytatás nélküli, lényeges-e vagy sem? Igen, mert eléggé pontos jele asszonyokhoz való viszonyomnak. De nem, mert ahhoz a képhez, ami erről a dologról meséimből kiderült, igazán új vonást nem tesz hozzá. A teljes képhez hozzátartoznék, a lényeghez, személyiségem, ember mivoltom lényegéhez nem feltétlenül. De ha nem feltétlenül, akkor lehet, hogy mégis. Végtére megint odajutok, hogy nem tudok dönteni.

Lehet, valamelyest fölment a teljesség lehetetlenségének tudata. Egy emberélet teljességének elmesélése - erről már gondolkodtam és meséltem egyszer - tán tovább is tartana, mint maga az élet. Az előbb említett mikrotörténés valós ideje is jóval rövidebb volt, mint amennyi ideig tartott az elmesélése. $\mathrm{Ha}$ a teljesség lehetetlen, akkor szükségképpen szelektálni kell, már csak a mesélés megkerülhetetlen időkorlátai, és persze a szelekció - lásd: felejtés részben önkéntelen korlátai miatt is bizonyára a felejtés, elfojtások martaléka lesz nagyon sok lényeges dolog is. Amikor tehát tudatosan szelektálok, és eldöntöm, hogy miről mesélek és miről nem, akkor nem tudhatom, a valóban lényeges vonások közül mi került a képbe, és mi nem. Könnyen lehet, hogy a képet jelentősen módosító történéselemek is - a felejtés mechanizmusának köszönhetően - hiányoznak. Úgy tűnik, a mese érvényességének ez az emlékezetműködés benne rejlő sajátosságaiból adódó bizonytalansága kiküszöbölhetetlen. Ezt is tudomásul kell venni. Akkor hát elégedjek meg annyival, amennyit elmeséltem? Abban az értelemben igen, hogy most, legalábbis egyelőre, ezt hangsúlyoznom kell, hogy egyelőre, hiszen ha adatik még néhány évem a tovább változásra, tovább-útkeresésre, később is lesz még mit, és kell még mit elmesélnem. Egyelőre tehát abbahagyom a mesélést. De hogy elégedett vagyok-e tartalmilag? Nos, ebben kétségem van. Elmondtam, elmeséltem annyit, amiből úgy véltem, tűrhetően nyomon követhető az út, a belső út is, amit megtettem. És ami olyanná tett, amilyennek ma vélem látni magamat. Jól-e? Követhetően-e? Netán tanulságokkal is szolgálhatóan-e? Nem tisztem ítélni efelöl. És nem mondom azt sem, hogy várom az esetleges olvasó ítéletét. Nem. Most úgy érzem, az már kívül van rajtam. Én elmondtam, amit, vélek, amit mondanom kellett. Ennyi. 